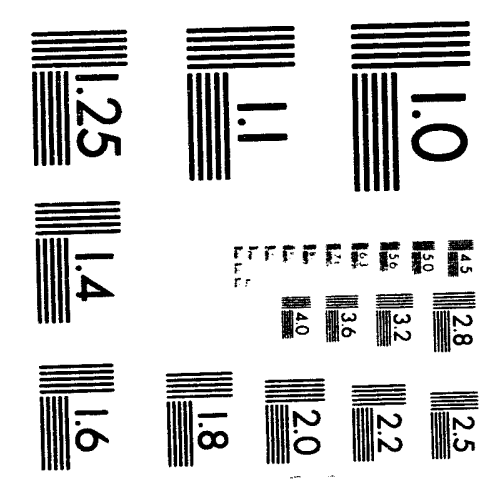



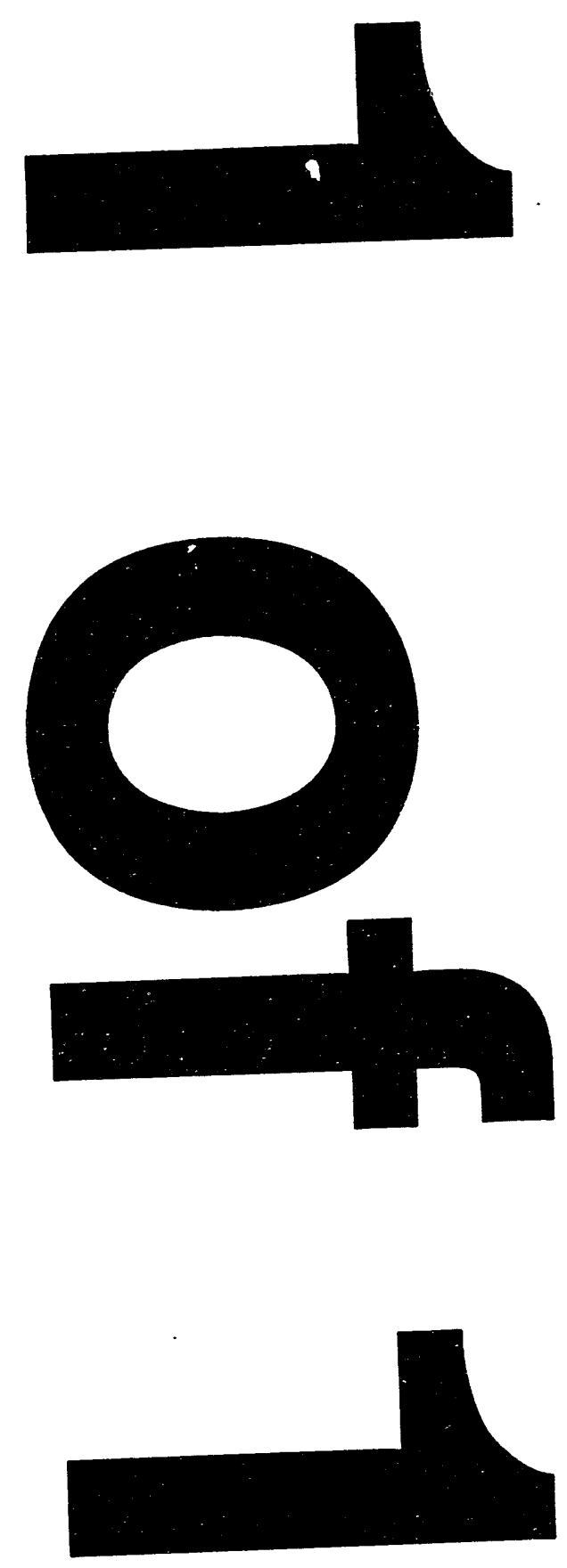
WHC-SA.0912-S

\title{
Handling and Disposal of SP-100 Ground Test Nuclear Fuel and Equipment
}

\author{
R. D. Hodgson \\ J. D. Potter \\ C. E. Wilson
}

in

Date Published

May 1990

To be presented at Bth Symposium on Space Nuclear Power Systems Albuquerque. New Mexico January 6-10, 1991

Prepared for the U.S. Department of Energy Assistant Secretary for Nuclear Energy

(2) Westingtrouser P.O. Box 1970

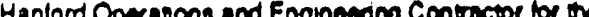

US. Departmont of Energy under Contract OE. AC 06.87 ALL 10030

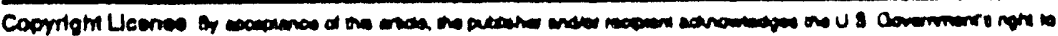

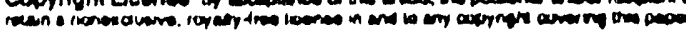

DISTRIBUTION OF THIS DOCUMENT IS UNLIMITED 
DISCLAIMER

This report was preosted as an account of work sponsored by an agency of the Uniled Siales Government. Neither the Unilod States Government nof any egancy inereol. nof any of iheif amployese, not any of their contractors, ivaiontractors of theit employees, makes any wartanty, oxpresed or implied. of assumes any logal liablity of cesponsibility lor the accuracy, cempleteness, or any third oarty's use of the results of such use of any inlormalion, apparatus. product, or procsese cisclosed, of represents that its use would not infringe privaloiy ownod nghts. Reforence herein to any specific commereal product, process, or sorvice by trade name. iracematk, manulscturep. of olherwise, does nol necessarity constitut of imoly its endorsement, recommendation, of lavering by the United Stales Oovernment of any agency thereol of its coneractors of subeontraciors. The viow and opinions ol authors expressed herein do not necesesanly slate of eolloct those of the United St. is Goveenment of any egoney inoreol.

Prowe in the Unow seowe wherese

$\operatorname{ascis} \cdot 2 \cdot \operatorname{crs} 12 \cdot \mathrm{m}$

-

$a$ 
HARDLIMG AM: IISPOSAL OF SP-100 GROUND TEST NUCLEAR FUEL AND EQUIPMENT

\author{
Charles E. Wilson \\ Jerry D. Potter and Richard D. Hodgson \\ Westinghouse Hanford Company \\ P.0. Box 1970 \\ Richiand, WA 39352 \\ (509) $376-3873$
}

\author{
Abstract
}

The post SP-100 reactor testing period will focus on defueling the reactor, packaging the various radioactive waste forms, and chipping this material to the appropriate locations. Remote-handling techniques will be developed to defuel the reactor. Packaging the spent fuel and activated reactor components is a challenge in itself. This paper presents an overview of the strategy, methods, and equipment that will be used during the closeout phase of nuclear

$\sim$ testing.

\title{
IHTRODUCTION
}

in important aspect of the SP-100 Ground Engineering System (GES) Test Site mission is the remote 1 , assembly of the nuclear reactor and radioactive cell equipment following completion of the nuclear testing program. Disassembly, packagtng, storage, and/or disposal of highly radioactive material is a sizable and complex undertaking. This paper presents an overview of the strategy, methods, and equipment that will be used to place the nuclear fuel and activated material into a safe and acceptable configuration.

\section{BACXGROUND}

Nuclear operation of the SP-100 reactor creates a significant quantity of highly radioactive fission material in the fuel ussemblies. Many of these ficsion elements are energetic elements. The high-energy neutron flux fields generated in the lower reactor cell during testing will activate most incell equipment and materials (reactor vessel, piping, etc.). As a result, highiy radioactive solid waste will be generated, along with the spent reactor fuel.

\section{The solld Hasta Sycle}

The solld waste material that will be produced by testing the SP-100 reactor is categorized as both low-level and high-level materlal. The low-level materlal will be slightly radloactive (up to $3 \mathrm{r} / \mathrm{h}$ contact) due to exposure from lower neutron flux flelds in the upper Test Assembly cell. This materlal will consist of the upper TA structure and piping located above the facility and flight shield. Most of the low-level material will be removed by hands-on methods. loaded into burlal boxes, and shipped to burial grounds on the Hanford site.

High-level solld waste (hundreds of $\mathrm{r} / \mathrm{h}$ at contact) wlll constst of artivated test assembly components, irradiated reactor core components, and in spent reactor fuel assemblles. 
Activated Niobium-lZr materiai will be packaged and stored onstic in a shielded cask for future shipment to a repository ficility. The nend for intertm storage arises from the high concentration of $94 \mathrm{fb}$ produced during operation of the SP-100 reactor.

Spent fuel assemblies will be removed from the core and packaged in stainless-steel containers. These containers wlll be loaded into a shielded cask. The cask will then be stored onsite for future shipment to a high-level waste repository facility.

\section{Remote Disassembly of the Test Assembly}

The SP-100 GES Test site includes a hot cell within the 309 Building containment building. The hot cell is separated into an upper cell and a lower cell. The equipment in the upper-cell area is partially shielded from the lower reactor cell by the reactor flight shield and a facility shield. These shields prevent significant activation of the upper test article equipment.

Disassembly of the TA will start after the primary lithium coolant and the secondary sodium coolant loops have been drained and cleaned. During the cleaning period, shielding windows, remote manipulators, and remote equipment throughways will be installet in the upper test cell.

The disassembly will begin with the removal of the upper vacuum vessel from the test cell. Remote pipe cutting equipment operated by the manipulators and the overhead cell bridge crane will sever piping and instrumentation lines connected to the upper vacuum vessel. Remote impact wrenches will be used to remove vacuum vessel flange bolts and other fasteners.

After the upper vacuum vessel section has been removed from the cell through the cell celling bagout ring, remcte tools will sever the TA heat exchanger, liquid metal surge tanks, and the two flow meters. This equipment is expected to be the most radioactive material in the upper cell and its presence would prevent manned entry into the cell. Once the most radloactive items are removed from the cell, facllity operators wlll manually section. pacxage, and remove the remaining pleces of the upper TA.

Several pieces of remote reactor-handling equipment will be installed in the upper test call when the upper call area has been cleaned. These components are the reactor's handling machinery, the reactor disassembly station, remote filel cantster welding station, and the fixture used to raise the reactor from the lower cell into the upper cell.

A lifting fixture will be remotely attached to the remaining section of the TA to access the SP-100 reactor. The lower TA sectlon will be llfted upward to bring the reactor to a position above the upper TA cell floor. At this time, the reactor handling machine will be activated and will place a holding fixture around and under the reactor vessel.

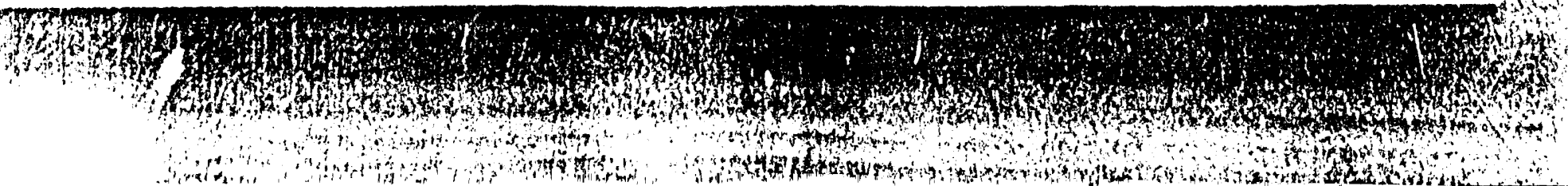


Reriote cutting tools will be used to sever the primary coolant piping close to the upper reactur flight shield. Remote l.ooing w1ll then access and remove the bolts holding the reactor vessel to the filght shield. When the reactor is separated from the flight shield, the reactor handing machine, supporting the weight of the reactor, will be moved to a holding position lear one of the cell walls. With the reactor cut of the way, the remains of the TA will be lowered back into place and secured.

The SP-100 reactor vessel will then be transferred to the reactor disassembly station by the reactor handing machine. At the disassembly station, the bottom portion of the reactor vassel will be cut away so that the lower face of the reactor core and fuel assemb'ies are exposed. Special tooling will be used to pull the assemblies out of the core and place them into individual stainless steel containers. These containers will be welded shut and leak-tested before being placed in a shielded cask.

\section{CONCLUSION}

The program to remove and package the radioactive solid waste generated during the testing of the $S P-100$ reactor will require the support of many pieces of equipment designed for remote and hostile environments. Handi ing of spent fuel in a hot-cell environment is not a new operation; however, the disassemoly of the $s p-100$ core will be an intricate tas'.

\section{Acknowledgments}

The author would like to acknowledge the contributions of the following group of SP-100 project personnel who devised, concelved, and are continuing to develop the equipment mentioned in this paper. These Hestinghouse Hanford employees are as follows:

Eric J. Shen, Project Engineer; Glenn E. Maiden, Computer Aid Designer; David P. Vader, Computer Ald Designer; James H. Perry, Lead Technicisn.

\section{Beferences}

Cenkey, E. J., G. D. Bazinet, E. J. Bltten, P. J. Brackenoury, W. F. Carlson, J. J. Irwin, P. A. Edwards, E. J. Shen, and P. A. Tltzler, 1989, "Definitive Design Status of the SP-100 Ground Engineering System Test Site," WHC-SA-0608-A, Westinghouse Hanford Company, presented at the 7 th Symposium on Space Nuclear Power Systems, Albuquerque, New Mexico.

Shen, E. J., L. J. Schweiger, and H. C. Miller of Westinghouse Hanford Company, R. Gluck and S. M. Davies of General Electric Company, 1988, "Selection of a Handling and Maintenance Option for the SP-100 Ground Engineering System Test," Seace Nuclear Power Systems 1987. M. S. El-Genk and M. D. Hoover, eds., Orbit Book Co., Malabar, Florida. 

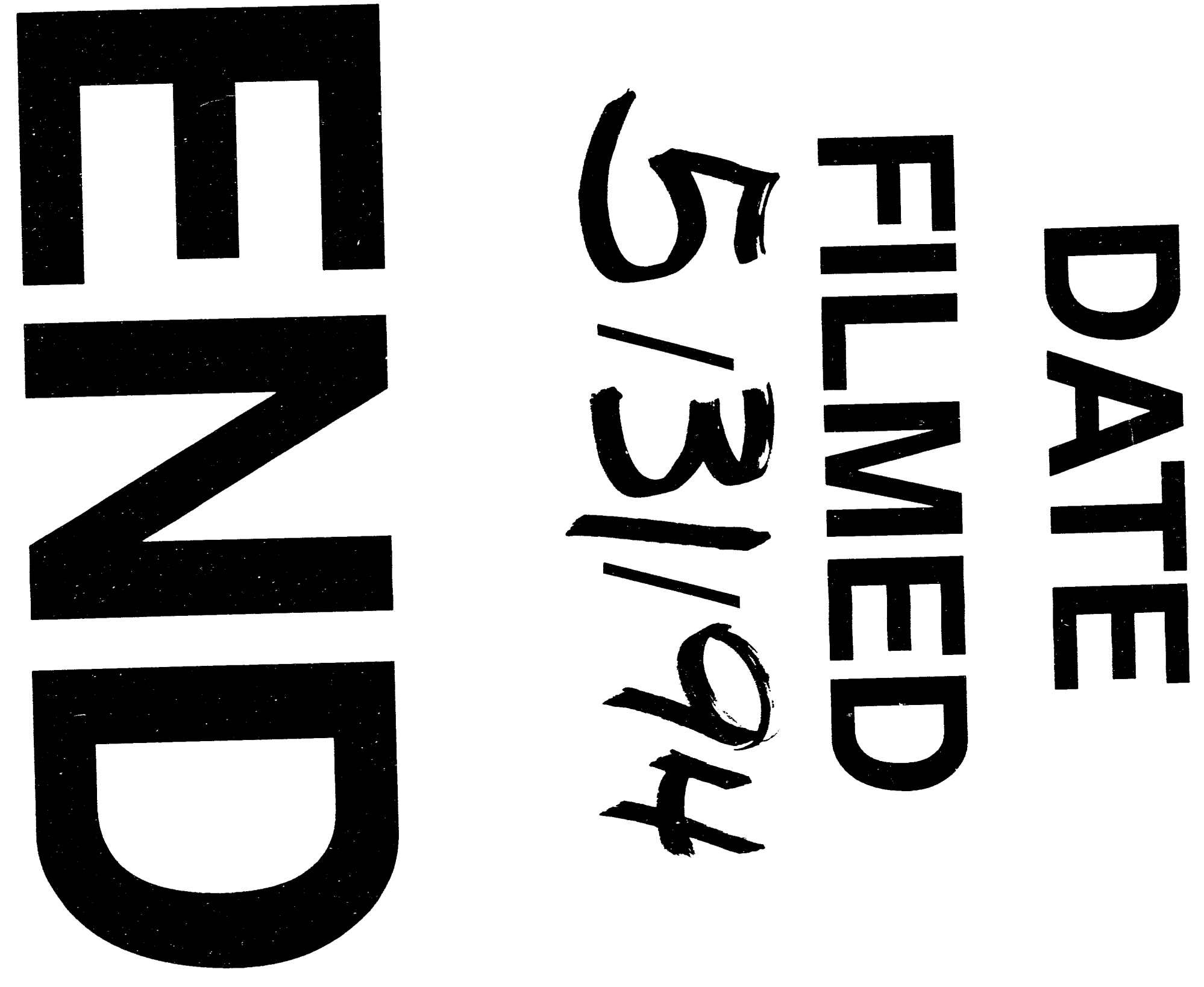
